


\title{
EVALUATION OF LACTICIN ADDITION ON GAS PRODUCTION KINETICS AND RUMEN METHANOGENESIS in Vitro
}

\author{
A. Jayanegara ${ }^{1,2}$, H.P.S. Makkar ${ }^{1}$ and K. Becker ${ }^{1}$ \\ ${ }^{1}$ Institute for Animal Production in the Tropics and Subtropics (480b), \\ University of Hohenheim, Fruwirthstrasse 12, 70593 Stuttgart - Germany \\ ${ }^{2}$ Permanent address: Department of Nutrition and Feed Technology, \\ Faculty of Animal Science, Bogor Agricultural University, \\ Jl. Agatis Kampus IPB Darmaga Bogor 16680 - Indonesia \\ Corresponding E-mail: anu_jayanegara@yahoo.com
}

Received January 22, 2014; Accepted February 27, 2014

\begin{abstract}
ABSTRAK
Tujuan penelitian ini adalah untuk mengamati efek sebuah bakteriosin yang relatif baru yakni laktisin 3147 terhadap kinetika produksi gas dan emisi metana dalam lingkungan rumen secara in vitro. Penelitian terdiri dari dua buah eksperimen. Eksperimen 1 menggunakan rancangan acak lengkap (tiga ulangan) untuk mengamati efek penambahan laktisin $(0$ dan $10 \mu \mathrm{M})$ pada substrat berupa rumput kering dan campuran rumput:konsentrat (1:1) terhadap kinetika produksi gas dan emisi metana. Pada eksperimen 2, level penambahan laktisin ditingkatkan menjadi 0, 10, 25 dan $50 \mu \mathrm{M}$. Substrat, laktisin dan campuran cairan rumen-buffer diinkubasi pada suhu $39^{\circ} \mathrm{C}$ selama 24 jam. Produksi total gas dan emisi metana diamati selama dan setelah periode inkubasi. Hasil menunjukkan bahwa secara umum penambahan laktisin tidak berpengaruh secara nyata terhadap peubah produksi gas dibandingkan dengan kontrol, baik ketika ditambahkan pada substrat berupa rumput maupun rumput:konsentrat. Penambahan laktisin hingga konsentrasi $50 \mu \mathrm{M}$ masih belum dapat menurunkan emisi metana, meskipun pada penambahan $25 \mu \mathrm{M}$ terdapat kecenderungan menurunkan emisi metana. Substrat berupa rumput menghasilkan metana yang lebih rendah secara signifikan dibandingkan dengan rumput:konsentrat baik pada eksperimen 1 maupun $2(\mathrm{P}<0,05)$. Dapat disimpulkan bahwa penambahan laktisin hingga $50 \mu \mathrm{M}$ masih belum dapat menurunkan emisi metana sehingga perlu diuji lebih lanjut pada konsentrasi yang lebih tinggi.
\end{abstract}

Kata kunci: laktisin, bakteriosin, metana, rumen, in vitro

\begin{abstract}
The present study was aimed to investigate the effect of a novel bacteriocin, i.e. lacticin 3147 , on gas production kinetics and methane emission under in vitro rumen environment in two consecutive experiments. In experiment 1 , either no or $10 \mu \mathrm{M}$ of lacticin was added to hay or hay:concentrate $(1: 1$, $\mathrm{w} / \mathrm{w})$ substrate. In experiment 2 , the levels of lacticin additions were extended to $0,10,25$ and $50 \mu \mathrm{M}$. Samples were incubated in three replicates in both experiments at $39^{\circ} \mathrm{C}$ for $24 \mathrm{~h}$. Total gas production and methane emission were measured during and after the incubation, respectively. Results revealed that, in general, addition of lacticin had limited significant effects on gas production parameters compared to control (without lacticin addition). Lacticin addition up to $50 \mu \mathrm{M}$ did not significantly decrease $\mathrm{CH}_{4}$ emission, although a tendency of methane reduction existed when lacticin was added at 25 $\mu \mathrm{M}$. Hay diet produced significantly less methane emission than that of hay:concentrate diet both in experiment 1 and experiment $2(\mathrm{P}<0.05)$. It can be concluded that lacticin addition up to $50 \mu \mathrm{M}$ was unable to decrease $\mathrm{CH}_{4}$ emission in vitro and therefore need to be tested further at higher concentrations.

Keywords: lacticin, bacteriocin, methane, rumen, in vitro
\end{abstract}

\section{INTRODUCTION}

Concern on global warming problem has received a lot of attention during the past decades.
A steady increase of earth surface temperature is considered to be due to the accumulation of some major green-house gases (GHG) such as carbon dioxide $\left(\mathrm{CO}_{2}\right)$, methane $\left(\mathrm{CH}_{4}\right)$, nitrogen oxide 
$\left(\mathrm{N}_{2} \mathrm{O}\right)$ and chloro fluoro carbon (CFC) through anthropogenic activities. Ruminant production system is a source of $\mathrm{CH}_{4}$ emission that contributes significantly by approximately 80 million tonnes of annual $\mathrm{CH}_{4}$ (Beauchemin et al., 2008). The gas itself is produced in the digestive tract of ruminants, particularly in the rumen, by methanogenic archaea via utilization of $\mathrm{CO}_{2}$ and $\mathrm{H}_{2}$ as their main substrates to form $\mathrm{CH}_{4}$ (Morgavi et al., 2010). Although such reaction is a way for eliminating the toxicity of $\mathrm{H}_{2}$ when being accumulated (McAllister and Newbold, 2008), the process can be optimized without confronting a normal rumen function. Further, in addition to its contribution to global warming, $\mathrm{CH}_{4}$ emission is a form of energy losses from ruminants which may account up to $14 \%$ of their digestible energy intake (Cottle et al., 2011).

A number of nutritional strategies have been attempted to mitigate ruminal $\mathrm{CH}_{4}$ emission. Bacteriocin, a proteinaceous substance produced by certain bacterial species to inhibit the growth of other species, is considered as a promising option in term of mitigating $\mathrm{CH}_{4}$. Nisin, a bacteriocin produced by certain strains of Lactococcus lactis, and bovicin HC5, a bacteriocin from Streptococcus bovis HC5, have been tested for their effects in inhibiting ruminal methanogenesis; both substances were demonstrated to mitigate ruminal $\mathrm{CH}_{4}$ emission under in vitro incubation system and the magnitudes of the effects were dose-dependent (Callaway et al., 1997; Lee et al., 2002). Further investigation on other bacteriocins that are effective in mitigating ruminal $\mathrm{CH}_{4}$ emissions has to be continued in order to obtain the most promising substance with regard to the objective while maintaining an optimum condition of general rumen fermentation.

Lacticin 3147 is a bacteriocin produced by Lactococcus lactis subsp. lactis DPC3147, a strain isolated from an Irish kefir grain that has a broad spectrum of inhibition and heat stable especially at low pH (Ryan et al., 1996). Due to its antimicrobial properties particularly by inhibiting a wide range of Gram-positive bacteria, lacticin has been used in a number of food and biomedical applications such as in cheese making, for the treatment and/or prevention of mastitis in cattle, and for treating some antibiotic resistant human pathogens (Twomey et al., 2002). Despite such beneficial effects of lacticin, the substance has not been assessed for its influence on rumen fermentation yet. Based on the anti-methanogenic effect of other bacteriocins, i.e. nisin and bovicin, therefore, lacticin may possess such property as well. The present study was therefore aimed to investigate the effect of lacticin addition on gas production kinetics and methane emission under in vitro rumen environment. The addition was done into two different substrates, i.e. hay or hay:concentrate $(1: 1, \mathrm{w} / \mathrm{w})$ and at various levels of application.

\section{MATERIALS AND METHODS}

\section{Experimental Design}

Lacticin 3147 was obtained from Dairy Products Research Centre, Teagasc, Moorepark, Republic of Ireland. Evaluation of the respective bacteriocin as an anti-methanogenic agent was performed in two consecutive experiments. In Experiment 1, a factorial completely randomized design was applied to examine the effects of different levels of lacticin $(0$ and $10 \mu \mathrm{M})$ added to hay or hay:concentrate $(1: 1, \mathrm{w} / \mathrm{w})$ substrates on gas production kinetics and $\mathrm{CH}_{4}$ emission. Experiment 2 was conducted as a continuation of Experiment 1 in order to confirm the results obtained and to increase the levels of lacticin used. The experimental set up of Experiment 2 was almost similar to Experiment 1, except that the levels of lacticin were extended to $0,10,25$ and $50 \mu \mathrm{M}$. In both experiments, samples were incubated in three replicates.

\section{In Vitro Gas Production}

Amounts of $380 \mathrm{mg}$ hay or hay:concentrate substrates (containing approximately 93\% dry matter) as basal diets were weighed and transferred into $100 \mathrm{ml}$ calibrated glass syringes (Haeberle Labortechnik GmbH \& Co. KG, Lonsee, Germany). The substrates were then added with $30 \mathrm{ml}$ of incubation medium (consisted of $10 \mathrm{ml}$ rumen liquor and $20 \mathrm{ml}$ buffer) by following the method of Menke and Steingass (1988). The rumen fluid and particulate matter were collected before the morning feeding from two rumen fistulated cows fed on roughage and concentrate based diets, mixed, homogenized, strained and filtered through $100 \mu \mathrm{m}$ nylon net. The glassware used was kept at approximately $39^{\circ} \mathrm{C}$ and flushed with $\mathrm{CO}_{2}$ before use. Lacticin was prepared by solubilizing it in sodium phosphate buffer at $\mathrm{pH}$ 6.8. Subsequently, the substance was injected $(\leq 1 \mathrm{ml})$ into $100 \mathrm{ml}$ calibrated syringe from the syringe nozzle before dispensing buffered rumen liquor. The $30 \mathrm{ml}$ 
buffered medium containing rumen microbes was thereafter dispensed into the syringes, and the incubation was carried out at $39^{\circ} \mathrm{C}$ for $24 \mathrm{~h}$.

\section{Chemical Analysis}

Hay and concentrate used as substrates in the present experiments were subjected to proximate (AOAC, 1990) and Van Soest analyses (Van Soest et al., 1991). Dry matter (DM) was determined by drying the samples at $105^{\circ} \mathrm{C}$ for $16 \mathrm{~h}$. Crude protein $(\mathrm{CP})$ was analysed using Kjeldahl method by considering $\mathrm{CP}=\mathrm{N} \times 6.25$, whereas ether extract (EE) was analysed based on Soxhlet extraction system using petroleum ether as the solvent. For the cell wall fractions, neutral detergent fiber (NDF) and acid detergent fiber (ADF) values are expressed inclusive of residual ash and without addition of amylase. Non-fiber carbohydrate was obtained by subtracting $\mathrm{CP}, \mathrm{EE}$ and NDF from organic matter. Chemical composition of the substrates is presented in Table 1.

\section{Gas Reading and Methane Determination}

During $24 \mathrm{~h}$ incubation period, the total gas was recorded at various time point interval from the calibrated scale on the syringe, i.e. at $0,4,8$ and $24 \mathrm{~h}$. At the end of incubation, methane production was measured using an infrared (0$30 \%$ range) methane analyser (Pronova Analysentechnik $\mathrm{GmbH}$ \& Co. KG, Berlin, Germany) calibrated against $10.6 \%$ methane (Jayanegara et al., 2009a). Technically, after measuring the total gas volume, the tubing of the syringe outlet was inserted into the inlet of the methane analyser. The display on the methane analyser gives methane as percent of the total gas and this value was used for calculation of methane in total gas volume.

\section{Data Analysis}

Kinetics of gas production during incubation period was fitted into an exponential equation proposed by Orskov and McDonald (1979) as follow:

$$
\mathrm{p}=\mathrm{a}+\mathrm{b}\left(1-\mathrm{e}^{-\mathrm{ct}}\right)
$$

Dependent variable $p$ is the cumulative gas production $(\mathrm{ml})$ at $\mathrm{t}$ hour incubation, whereas $\mathrm{a}, \mathrm{b}$ and $\mathrm{c}$ are the constants of the equation. The constants are interpreted as gas production from soluble feed fraction (a), gas production from insoluble but fermentable fraction (b), and rate of gas production (c). Thus $a+b$ is the theoretical
Table 1. Chemical Composition of Hay (H), Concentrate (C) and Hay:Concentrate (HC; 1:1, $\mathrm{w} / \mathrm{w})$ Used as Substrates in the in vitro Incubation (in \% Dry Matter)

\begin{tabular}{lrrr}
\hline Component & $\mathrm{H}$ & $\mathrm{C}$ & $\mathrm{HC}$ \\
\hline & $\ldots \ldots \ldots \ldots . . \% \ldots \ldots \ldots \ldots \ldots . . . . \ldots \ldots$ \\
Dry matter & 93.6 & 93.0 & 93.3 \\
Organic matter & 89.3 & 95.6 & 92.5 \\
Crude ash & 10.7 & 4.4 & 7.5 \\
Crude protein & 11.2 & 19.3 & 15.3 \\
Ether extract & 2.0 & 1.6 & 1.8 \\
Neutral detergent fiber & 52.8 & 17.3 & 35.1 \\
Acid detergent fiber & 32.6 & 5.8 & 19.2 \\
Non-fiber carbohydrate* & 23.3 & 57.4 & 40.3 \\
\hline * Defined as: organic matter - (crude protein + ether \\
extract + neutral detergent fiber)
\end{tabular}

maximum gas production during incubation at infinite thour (the asymptotic value).

Data obtained were analysed using factorial analysis of variance (ANOVA). The factors were substrate (hay or hay:concentrate, 1:1 w/w) and level of lacticin addition. Allocation of factors or treatments into incubation units were based on a completely randomized design. When at least a factor showed significantly different at $\mathrm{P}<0.05$, the analysis was continued using Tukey's test for a more specific treatment comparison. All statistical analyses were performed using STATISTICA software version 6.0.

\section{RESULTS AND DISCUSSION}

\section{Gas Production Kinetics}

In general, addition of lacticin had limited significant effects on gas production parameters compared to control (without lacticin addition). This was true for hay and hay:concentrate substrates, and was consistently observed both in Experiment 1 (Table 2) and Experiment 2 (Table 3). However, there were few exceptions: addition of $10 \mu \mathrm{M}$ lacticin to hay substrate decreased gas production at 4 and $8 \mathrm{~h}(\mathrm{P}<0.05$; Experiment 1$)$, and addition of $50 \mu \mathrm{M}$ lacticin to hay:concentrate decreased gas production at $24 \mathrm{~h} \quad(\mathrm{P}<0.05$; Experiment 2). The respective results suggest that 
lacticin addition up to $50 \mu \mathrm{M}$ does not influence fermentation and digestion of carbohydrate (both fiber and starch). Since lacticin is basically a polypeptide, hence, addition of lacticin is theoretically increases protein content in the in vitro system. Apart from the fact that gas production from protein fermentation is relatively small as compared to that of carbohydrate (Getachew et al., 1998), addition a proteinacous substance up to $50 \mu \mathrm{M}$ is considered to be too small to influence the change of total gas production.

The main source of variation that led to differences in gas production parameters was the different incubated substrates, i.e. between hay and hay:concentrate. It had to be noted that the differences did not appear during early fermentation period $(<8 \mathrm{~h})$, but the differences were significants at $24 \mathrm{~h}(\mathrm{P}<0.05)$; higher gas production in the incubation of hay:concentrate compared to hay was observed both in experiment 1 and experiment 2 at $24 \mathrm{~h}$ fermentation period $(\mathrm{P}<0.05)$. For the gas production kinetics parameters, $a+b$ was higher in the incubation of hay:concentrate compared to that of hay in experiment 1 and $2(\mathrm{P}<0.05)$. Interaction between substrate and lacticin addition was found to be significantly different in experiment 2 ; lower $a+b$ was observed at higher levels of lacticin addition $(\mathrm{P}<0.05)$. Conversely to the previous parameter, $\mathrm{c}$ was significantly higher in the incubation of hay compared to hay:concentrate both in experiment 1 and experiment $2 \quad(\mathrm{P}<0.05)$. No interaction between substrate and lacticin addition was observed for the rate of gas production parameter.

Higher gas production in the incubation of hay:concentrate substrate compared to hay was due to higher proportion of non-fiber carbohydrate and lower proportion of fiber fraction (both NDF and ADF) in hay:concentrate. It has been well-established that fiber, i.e. structural components of plant such as NDF, ADF, cellulose and lignin, is negatively influenced the feed quality and digestibility (Jayanegara et al., 2009b). On the contrary, non-structural carbohydrate like starch, which is presumably high in concentrate, is considered to be positively correlated with feed quality. It is therefore not surprising that incubation of hay:concentrate substrate produced higher gas production over the hay only substrate. In agreement with the results, Jayanegara et al. (2009c) observed that substrates with higher ADF contents produced less total gas production and lower organic matter digestibility as shown by the correlation coefficients between the respective parameters. Further, addition of concentrate may stimulate rumen microbial activity and population and, in turn, contributes to the overall fermentation and digestion process.

Table 2. Influence of Addition of Lacticin 3147 to Different Substrates on Gas Production Kinetics (Experiment 1)

\begin{tabular}{|c|c|c|c|c|c|c|}
\hline \multirow{2}{*}{$\begin{array}{c}\text { Substrate } \\
\text { (S) }\end{array}$} & \multirow{2}{*}{$\begin{array}{l}\text { Lacticin } \\
(\mathrm{L} ; \mu \mathrm{M})\end{array}$} & \multicolumn{3}{|c|}{ Gas Production (mL) } & \multirow{2}{*}{$\mathrm{a}+\mathrm{b}(\mathrm{mL})$} & \multirow{2}{*}{$\mathrm{c}(\mathrm{mL} / \mathrm{h})$} \\
\hline & & $4 \mathrm{~h}$ & $8 \mathrm{~h}$ & $24 \mathrm{~h}$ & & \\
\hline \multirow[t]{2}{*}{$\mathrm{H}$} & 0 & $23.5^{\mathrm{b}}$ & $42.0^{\mathrm{b}}$ & $76.6^{\mathrm{a}}$ & $91.7^{\mathrm{a}}$ & $0.076^{\mathrm{b}}$ \\
\hline & 10 & $21.7^{\mathrm{a}}$ & $39.8^{\mathrm{a}}$ & $74.0^{\mathrm{a}}$ & $90.5^{\mathrm{a}}$ & $0.071^{b}$ \\
\hline \multirow[t]{2}{*}{$\mathrm{HC}$} & 0 & $22.8^{\mathrm{b}}$ & $42.2^{b}$ & $89.1^{\mathrm{b}}$ & $128.2^{\mathrm{b}}$ & $0.050^{\mathrm{a}}$ \\
\hline & 10 & $22.7^{\mathrm{b}}$ & $41.3^{\mathrm{b}}$ & $85.6^{\mathrm{b}}$ & $118.3^{b}$ & $0.054^{\mathrm{a}}$ \\
\hline SEM & & 0.216 & 0.310 & 1.985 & 5.314 & 0.004 \\
\hline \multicolumn{7}{|l|}{ P-value } \\
\hline$S$ & & 0.049 & ns & $<0.001$ & $<0.001$ & $<0.001$ \\
\hline $\mathrm{L}$ & & 0.001 & 0.002 & ns & ns & ns \\
\hline $\mathrm{S} * \mathrm{~L}$ & & 0.004 & ns & ns & ns & $\mathrm{ns}$ \\
\hline
\end{tabular}

$\mathrm{H}$, hay; HC, hay:concentrate $(1: 1, \mathrm{w} / \mathrm{w})$; SEM, standard error of the mean Superscripts with different letters are significantly different at $\mathrm{P}<0.05$ 
Table 3. Influence of Addition of Lacticin 3147 to Different Substrates on Gas Production Kinetics (Experiment 2)

\begin{tabular}{|c|c|c|c|c|c|c|}
\hline \multirow{2}{*}{$\begin{array}{c}\text { Substrate } \\
\text { (S) }\end{array}$} & \multirow{2}{*}{$\begin{array}{l}\text { Lacticin } \\
(\mathrm{L} ; \mu \mathrm{M})\end{array}$} & \multicolumn{3}{|c|}{ Gas production $(\mathrm{mL})$} & \multirow{2}{*}{$\mathrm{a}+\mathrm{b}(\mathrm{mL})$} & \multirow{2}{*}{$\mathrm{c}(\mathrm{mL} / \mathrm{h})$} \\
\hline & & $4 \mathrm{~h}$ & $8 \mathrm{~h}$ & $24 \mathrm{~h}$ & & \\
\hline \multirow[t]{4}{*}{$\mathrm{H}$} & 0 & 25.3 & 45.0 & $77.2^{\mathrm{ab}}$ & $88.0^{\mathrm{a}}$ & $0.088^{b c}$ \\
\hline & 10 & 26.3 & 46.0 & $77.3^{\mathrm{ab}}$ & $86.7^{\mathrm{a}}$ & $0.093^{b c}$ \\
\hline & 25 & 26.0 & 45.8 & $75.0^{\mathrm{a}}$ & $83.1^{\mathrm{a}}$ & $0.098^{\mathrm{c}}$ \\
\hline & 50 & 24.8 & 44.3 & $77.8^{b}$ & $90.2^{\mathrm{a}}$ & $0.083^{\mathrm{b}}$ \\
\hline \multirow[t]{4}{*}{$\mathrm{HC}$} & 0 & 25.0 & 45.3 & $90.8^{d}$ & $119.9^{c}$ & $0.059^{\mathrm{a}}$ \\
\hline & 10 & 25.5 & 45.8 & $90.0^{\mathrm{cd}}$ & $115.7^{\mathrm{bc}}$ & $0.063^{\mathrm{a}}$ \\
\hline & 25 & 26.3 & 46.8 & $91.8^{\mathrm{d}}$ & $117.5^{\mathrm{bc}}$ & $0.064^{\mathrm{a}}$ \\
\hline & 50 & 25.5 & 45.5 & $87.5^{\mathrm{c}}$ & $109.7^{b}$ & $0.067^{\mathrm{a}}$ \\
\hline SEM & & 0.148 & 0.181 & 1.646 & 3.63 & 0.004 \\
\hline \multicolumn{7}{|l|}{$\mathrm{P}$-value } \\
\hline$S$ & & ns & ns & $<0.001$ & $<0.001$ & $<0.001$ \\
\hline $\mathrm{L}$ & & ns & ns & ns & ns & ns \\
\hline $\mathrm{S} * \mathrm{~L}$ & & ns & ns & ns & 0.013 & $\mathrm{~ns}$ \\
\hline
\end{tabular}

$\mathrm{H}$, hay; HC, hay:concentrate (1:1, w/w); SEM, standard error of the mean

Superscripts with different letters are significantly different at $\mathrm{P}<0.05$

\section{Ruminal Methane Emission}

Lacticin up to $50 \mu \mathrm{M}$ did not significantly influence $\mathrm{CH}_{4}$ emission when added to hay or hay:concentrate substrate. This was consistently observed in experiment $1(10 \mu \mathrm{M}$ lacticin; Figure 1) and experiment $2(10-50 \mu \mathrm{M}$ lacticin; Figure 2). However, a tendency of methane reduction existed when lacticin was added at $25 \mu \mathrm{M}$ (experiment 2 ) especially in the hay substrate. It appears that lacticin up to $50 \mu \mathrm{M}$ is still ineffective to be used for modifying rumen fermentation, including for mitigating $\mathrm{CH}_{4}$ emission. As for other bacteriocins like nisin and bovicin in which their effects are dose-dependent (Callaway et al., 1997; Lee et al., 2002), it seems that lacticin at such concentration is still below a threshold level to significantly decrease $\mathrm{CH}_{4}$ emission. This certainly opens the opportunity for further subsequent studies to test lacticin at higher levels of addition. Apart from that, Kalmokoff $e t$ al. (1996) stated that the effectifity of a certain bacteriocin in the rumen depends on its stability against ruminal proteolytic. Therefore it is probable that lacticin may loss part of its activity due to proteolytic mechanism occurring intensively in rumen environment.
As observed for gas production parameter, variation of $\mathrm{CH}_{4}$ emission due to substrate different was also existed. In this study, hay:concentrate diet produced higher $\mathrm{CH}_{4}$ than that of hay as consistently observed both in experiment 1 and experiment $2(\mathrm{P}<0.05)$. Such a result apparently contrasts to a commonly known concept that increasing proportion of concentrate instead of forage in diet would reduce methane emission from ruminants (Beauchemin et al., 2008). The concept is based on a theory that feeding of concentrate favors propionate production in the rumen over the acetate so that more hydrogen is being utilized rather than being produced. Furthermore, the concentrate creates unconducive rumen environment for the archaea methanogens by increasing rate of passage, lowering $\mathrm{pH}$ and eliminating some population of protozoa where part of the methanogens are symbiotically living together with the protozoa (Moss et al., 2000).

It has to be noted, however, that methane decrease by increasing level of concentrate in the diet is usually expressed in a relative unit, such as relative to gross energy intake or digestible energy intake or relative to unit of animal product (such 


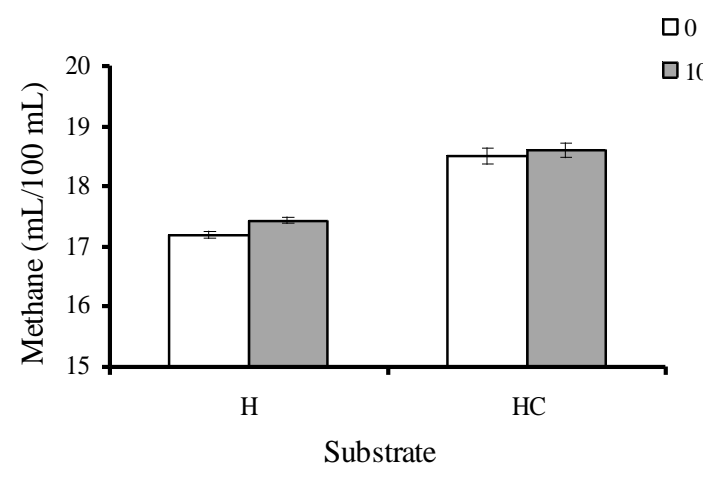

Figure 1. Ruminal Methane Emission on the Addition of Lacticin $3147(0$ and $10 \mu \mathrm{M})$ to Different Substrates (Experiment 1). H, hay; HC, hay:concentrate $(1: 1, \mathrm{w} / \mathrm{w})$. P-value: substrate, $<0.001$; lacticin, ns; substrate*lacticin, $\mathrm{n}$

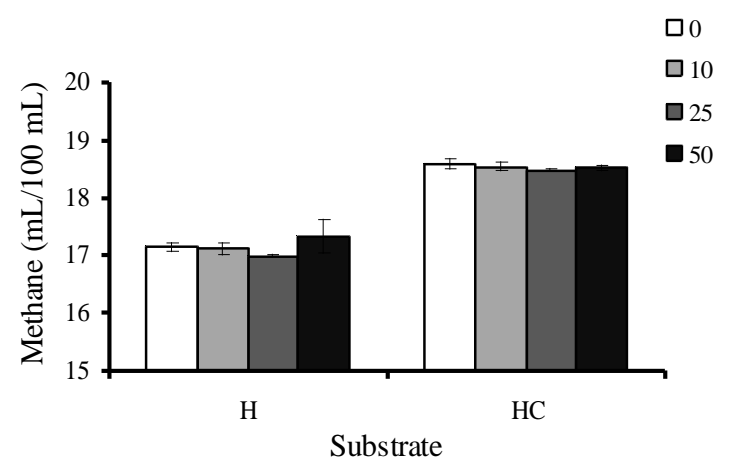

Figure 2. Ruminal Methane Emission on the Addition of Lacticin $3147(0,10,25$ and $50 \mu \mathrm{M})$ to Different Substrates (Experiment 2). H, hay; $\mathrm{HC}$, hay:concentrate $(1: 1, \quad \mathrm{w} / \mathrm{w})$. P-value: substrate, <0.001; lacticin, ns; substrate*lacticin, ns

as per unit of milk produced or body weight). When methane emission is expressed in an absolute unit, such 1/day or mol/day, interestingly, the emission is higher at higher level of concentrate in the diet. For instance, in an in vitro study, Garcia-Martinez et al. (2005) showed that methane productions of high, medium and low forage diets were 701, 754 and $812 \mu \mathrm{mol}$, which indicated that higher proportion of concentrate led to a higher absolute methane emissions. In agreement with the study, Lovett et al. (2003) found that absolute methane emissions (in L/day) were higher when finishing beef heifers were fed with a diet containing $60 \%$ concentrate as compared to those of fed with a diet containing $35 \%$ concentrate. But, methane emission per unit of animal product (per $\mathrm{kg}$ of live weight gain and carcass gain; in a relative unit) was reduced by lower forage to concentrate ratio. A plausible explanation to such contrasting results is that, although there is a shift towards more propionate by increasing proportion of concentrate in the diet, the concentrate is clearly more digestible than that of forage. As a consequence, on the whole, hydrogen is produced more as well as the methane emission.

\section{CONCLUSION}

Lacticin addition up to $50 \mu \mathrm{M}$ was unable to significantly decrease $\mathrm{CH}_{4}$ emission in vitro. It seems that lacticin at such concentration is still below a threshold level to create such an effect. Despite the fact, a tendency of methane reduction existed when lacticin was added at $25 \mu \mathrm{M}$. Further studies are therefore required to test lacticin at higher concentrations in order to decrease methanogenesis at simultaneously improving rumen fermentation activity.

\section{REFERENCES}

Association of Official Analytical Chemists (AOAC). 1990. Official Methods of Analysis. $15^{\text {th }}$ ed. Association of Official Analytical Chemists, Arlington, VA, USA.

Beauchemin, K.A., M. Kreuzer, F. O'Mara and T.A. McAllister. 2008. Nutritional management for enteric methane abatement: a review. Aust. J. Exp. Agric. 48:21-27

Callaway, T.R., A.M.S. Carneiro De Melo and J.B. Russell. 1997. The effect of nisin and monensin on ruminal fermentations in vitro. Curr. Microbiol. 35:90-96

Cottle, D.J., J.V. Nolan and S.G. Wiedemann. 2011. Ruminant enteric methane mitigation: a review. Anim. Prod. Sci. 51:491-514

Garcia-Martinez, R., M.J. Ranilla, M.L. Tejido and M.D. Carro. 2005. Effects of disodium fumarate on in vitro rumen microbial growth, methane production and fermentation of diets differing in their forage:concentrate ratio. Brit. J. Nutr. 94:7177

Getachew, G., M. Blümmel, H.P.S. Makkar and K. Becker. 1998. In vitro gas measuring 
techniques for assessment of nutritional quality of feeds: a review. Anim. Feed Sci. Technol. 72:261-281

Jayanegara, A., N. Togtokhbayar, H.P.S. Makkar and K. Becker. 2009a. Tannins determined by various methods as predictors of methane production reduction potential of plants by an in vitro rumen fermentation system. Anim. Feed Sci. Technol. 150:230-237

Jayanegara, A., H.P.S. Makkar and K. Becker. 2009b. The use of principal component analysis in identifying and integrating variables related to forage quality and methane production. J. Indon. Trop. Anim. Agric. 34:241-247

Jayanegara, A., A. Sofyan, H.P.S. Makkar and K. Becker. 2009c. Gas production kinetics, organic matter digestibility and methane production in vitro in hay and straw diets supplemented by tannin-containing forages. Med. Pet. 32:120-129.

Kalmokoff, M.L., F. Bartlett and R.M. Teather. 1996. Are ruminal bacteria armed with bacteriocins? J. Dairy Sci. 79:2297-2306

Lee, S.S., J.T. Hsu, H.C. Mantovani and J.B. Russell. 2002. The effect of bovicin HC5, a bacteriocin from Streptococcus bovis HC5, on ruminal methane production in vitro. FEMS Microbiol. Lett. 217:51-55

Lovett, D., S. Lovell, L. Stack, J. Callan, M. Finlay, J. Conolly and F.P. O'Mara. 2003. Effect of forage/concentrate ratio and dietary coconut oil level on methane output and performance of finishing beef heifers. Livest. Prod. Sci. 84:135-146.

McAllister, T.A., and C.J. Newbold. 2008. Redirecting rumen fermentation to reduce methanogenesis. Aust. J. Exp. Agric. 48:713.

Menke, K.H., and H. Steingass. 1988. Estimation of the energetic feed value obtained from chemical analysis and in vitro gas production using rumen fluid. Anim. Res. Dev. 28:7-55

Morgavi, D.P., E. Forano, C. Martin and C.J. Newbold. 2010. Microbial ecosystem and methanogenesis in ruminants. Animal 4:1024-1036

Moss, A.R., J.P. Jouany and J. Newbold. 2000. Methane production by ruminants: its contribution to global warming. Ann. Zootech. 49:231-253

Orskov, E.R., and I. McDonald. 1979. The estimation of protein degradability in the rumen from incubation measurements weighted according to rate of passage. J. Agric. Sci. 92:499-503

Ryan, M.P., M.C. Rea, C. Hill and R.P. Ross. 1996. An application in cheddar cheese manufacture for a strain of Lactococcus lactis producing a novel broad-spectrum bacteriocin, lacticin 3147. Appl. Environ. Microbiol. 62:612-619

Twomey, D., R.P. Ross, M. Ryan, B. Meaney and C. Hill. 2002. Lantibiotics produced by lactic acid bacteria: structure, function and applications. Antonie van Leeuwenhoek 82:165-185

Van Soest, P.J., J.B. Robertson and B.A. Lewis. 1991. Methods for dietary fiber, neutral detergent fiber, and nonstarch polysaccharides in relation to animal nutrition. J. Dairy Sci. 74:3583-3597 